\title{
Prepartum body condition score affects milk yield, lipid metabolism, and oxidation status of Holstein cows
}

\author{
Wei Zhao ${ }^{1,2}$, Xue Chen ${ }^{1,2}$, Jun Xiao ${ }^{2}$, Xiao Hui Chen ${ }^{1}$, Xue Feng Zhang ${ }^{1,2,3,4}$, \\ Tao Wang ${ }^{1,2,3,4}$, Yu Guo Zhen ${ }^{1,2,3,4, *}$, and Gui Xin Qin ${ }^{1,3,4, *}$
}

\author{
* Corresponding Authors: \\ Yu Guo Zhen \\ Tel: +86-431-8453-3231, Fax: +86-431-8453-2992, \\ E-mail: nickzhen@263.net \\ Gui Xin Qin \\ Tel: +86-431-8453-3231, Fax: +86-431-8453-2992, \\ E-mail: qgx@jlau.edu.cn
}

${ }^{1}$ College of Animal Science and Technology, Jilin Agricultural University, Changchun 130118, China

2 JLAU-Borui Dairy Science and Technology R\&D

Centre of Jilin Agricultural University, Changchun 130118, China

${ }^{3}$ Key Laboratory of Animal Production, Product Quality and Security, Ministry of Education, Jilin Agricultural University, Changchun 130118, China

${ }^{4}$ Key Laboratory of Animal Nutrition and Feed

Science of Jilin Province, Jilin Agricultural University,

Changchun 130118, China

ORCID

Wei Zhao

https://orcid.org/0000-0002-3052-3123

Xue Chen

https://orcid.org/0000-0001-7537-1525

Jun Xiao

https://orcid.org/0000-0001-6841-438X

Xiao Hui Chen

https://orcid.org/0000-0002-8218-8582

Xue Feng Zhang

https://orcid.org/0000-0002-7676-0319

Tao Wang

https://orcid.org/0000-0002-1876-0097

Yu Guo Zhen

https://orcid.org/0000-0002-6966-6965

Gui Xin Qin

https://orcid.org/0000-0001-6918-1709

Submitted Oct 30, 2018; Revised Jan 23, 2019; Accepted Mar 22, 2019
Objective: This study aimed to investigate the effects of prepartum body condition score (BCS) on the milk yield, lipid metabolism, and oxidative status of Holstein cows.

Methods: A total of 112 multiparous Holstein cows were divided into 4 groups according to the BCS at 21 days before calving: medium BCS (3.0 to 3.25, MBCS), high BCS (3.5 to 3.75, HBCS), higher BCS (4.0 to 4.25, HerBCS), and highest BCS (4.5 to 5.0, HestBCS). Blood samples were collected on 21,14 , and 7 days before calving (precalving), on the calving day (calving), and on 7, 14, and 21 days after calving (postcalving). The indices of lipid metabolism and oxidative status were analyzed using bovine-specific enzyme-linked immunosorbent assay kit. Colostrum were taken after calving and analyzed by a refractometer and milk analyzer. The individual milk yield was recorded every 3 days.

Results: The density and levels of immune globulin and lactoprotein of colostrum from Holstein cows in the HestBCS group were the highest $(\mathrm{p}<0.05)$. These animals not only had the highest $(p<0.05)$ levels of serum non-esterified fatty acids and beta-hydroxybutyrate, but also had the highest $(\mathrm{p}<0.05)$ levels of malondialdehyde, superoxide dismutase, catalase, vitamin $\mathrm{A}$, and vitamin $\mathrm{E}$. In addition, greater $(\mathrm{p}<0.05) \mathrm{BCS}$ loss was observed in the HestBCS cows.

Conclusion: This study demonstrates that the milk yield, lipid metabolism, and oxidative status of Holstein cows are related to prepartum BCS and BCS loss during the transition period. HestBCS cows are more sensitive to oxidative stress and suffer greater loss of BCS after calving, whereas the MBCS animals had better milk yield performance.

Keywords: Milk Production; Lipid Metabolism; Oxidative Stress; Transition Period; Body Condition Score Loss

\section{INTRODUCTION}

In the transition period, dairy cows experience oxidative stress and are susceptible to metabolic disorders and immunologic challenges [1,2]. At the time of early lactation, cows go through a period of negative energy balance (NEB) which may lead to oxidative stress and health problems in these animals [3]. Early lactation NEB not only decreases milk yield but also increased concentrations of non-esterified fatty acids (NEFA) and beta-hydroxybutyrate (BHBA) [4,5]. NEFA in the blood is mobilized from adipose tissue while BHBA is an intermediate metabolite of fatty acid oxidation [6]. NEFA and BHBA are considered to be biomarkers of NEB, and oxidative stress during the transition period $[7,8]$. The body condition score (BCS) is an assessment of body fat and reflects the NEB of Holstein dairy cows $[9,10]$. It was reported that the BCS of cows were associated with differences in milk production and composition, reproduction, and health [7,11]. Cows with higher BCS at calving had higher concentrations of NEFA $[12,13]$ and BHBA [13] in early lactation com- 
pared these with lower BCS. Cows with higher BCS are more sensitive to oxidative stress $[14,15]$. Oxidative stress is mainly derived from an imbalance between reactive oxygen metabolites and antioxidants and the concentration of some oxidative status indices such as malondialdehyde (MDA) was higher in cows with higher BCS before calving [15].

But the change of BCS during the transition period and their effects on the health and subsequent performance of dairy cows was few systematically studied. Therefore, the relations between the BCS and milk production, lipid metabolism, oxidative status of dairy cows were investigated in the present study. Consequently, this study may be used as reference for the dairy farms to improve the animals' health status and performance by adjusting prepartum BCS.

\section{MATERIALS AND METHODS}

\section{Animals and experimental design}

The trial was carried out at a commercial dairy farm with about 5,000 lactating cows in Dongying City, Shandong Province, P.R. China. The average milk yield per lactation of the cows was more than $40 \mathrm{~kg}$ (305 day). The BCS (5-point scale) was individually recorded 21 days before calving, on the calving day and 21 days after calving [9]. Multiparous Holstein cows (second or third lactation) were selected according to their BCS at 21 days before calving and divided into 4 groups (28 animals per group): medium BCS (3.0 to 3.25, MBCS), high BCS ( 3.5 to 3.75 , HBCS), higher BCS (4.0 to 4.25 , HerBCS), and highest BCS ( 4.5 to 5.0 , HestBCS). The cows were given access to total mixed ration and water ad libitum. The cows received a far-off diet $(1.33 \mathrm{Mcal} / \mathrm{kg})$ from $-60 \mathrm{~d}$ to $-22 \mathrm{~d}$, and a close-up diet $(1.50 \mathrm{Mcal} / \mathrm{kg})$ was offered during the last $21 \mathrm{~d}$. From 4 to 6 days postpartum, cows were supplemented with propylene glycol (PG, $300 \mathrm{~mL}$ ) as a gluconeogenic precursor for both treatment and prevention of ketosis during transition. Cows were fed lactation diet I until $21 \mathrm{~d}$ (1.78 $\mathrm{Mcal} / \mathrm{kg})$ and lactation diet II ( $1.83 \mathrm{Mcal} / \mathrm{kg})$ from $22 \mathrm{~d}$ to $100 \mathrm{~d}$ and milked four times at approximately 6:00, 12:00, 18:00, and 0:00; the individual milk yield was recorded every 3 days. The compositions of the diets are shown in Table 1 [16]. All of the animal experimental procedures were approved by the Institutional Animal Care and Use Committee at Jilin Agricultural University.

\section{Blood and milk samples}

Blood was sampled via the coccygeal vein after morning feeding at days 21,14 , and 7 prepartum (precalving), day 0 (calving), and days 7,14 , and 21 postpartum (after calving). Serum was collected in $(1.5 \mathrm{~mL})$ after centrifuging at $2,000 \times g$ at $4^{\circ} \mathrm{C}$ for $10 \mathrm{~min}$ and stored at $-20^{\circ} \mathrm{C}$ until analytical determination. Colostrum was taken immediately after calving, and the levels of lactoprotein, lactose, solid-not-fat, and ash were analyzed by a milk analyzer (Foss Electric, Hillerød, Denmark) while the density and immune globulin concentration were analyzed by a refractometer (Yucheng To You Optical Instruments Co. Ltd., Shandong, China). The concentrations of NEFA, BHBA, superoxide dismutase (SOD), MDA, catalase (CAT), vitamin $\mathrm{A}$ (VA) and vitamin $\mathrm{E}$ (VE) in serum were analyzed using commercial bovine specific enzyme-linked immunosorbent assay kits (Shanghai Enzyme-linked Biotechnology Co. Ltd., Shanghai, China) according to the instructions. Reaction is terminated by sulphuric acid. The color change is measured spectrophotometrically at a wavelength of $450 \mathrm{~nm}$ (Multiskan FC, Thermo scientific, Waltham, MA, USA) and calculated by comparing the optical density of the samples to the standard curve, respectively.

\section{Statistical analysis}

All of the data are presented as the means \pm standard error and were subjected to one-way analysis of variance (colostrum composition) and general linear model by SPSS computer software (SPSS Inc., Chicago, IL, USA). The specify model included BCS (MBCS, HBCS, HerBCS, and HestBCS), Time (precalving, calving, postcalving) and their interactions (BCS $\times$ time) as fixed effects and cow within the treatment as random effect. Statistical significance is defined when $p$ values are less than 0.05 . Pearson correlation coefficients among the detected parameters were also calculated.

\section{RESULTS}

\section{Colostrum composition, milk yield, and body condition score loss}

The density of colostrum and the levels of immune globulin and lactoprotein of cows in the HestBCS group were higher $(p<0.05)$ than those in the other groups (Table 2). The milk yields of cows in the MBCS, HBCS, HerBCS, and HestBCS groups peaked ( $\geq 50 \mathrm{~kg} / \mathrm{d}$ ) at days 19 to 82,22 to 100,25 to 73 , and 31 to 97 , respectively. The average milk yields ( 0 to 100 days) were $52.35 \mathrm{~kg} / \mathrm{d}, 50.94 \mathrm{~kg} / \mathrm{d}, 48.59 \mathrm{~kg} / \mathrm{d}$, and 48.78 $\mathrm{kg} / \mathrm{d}$, respectively (Figure 1; Table 2). In addition, the present data showed that the animals in the HestBCS group had a greater BCS loss after calving (Figure 2). The percentages of lost BCS were 23.62\% (HestBCS), 14.36\% (HerBCS), 13.33\% (HBCS), and 5.53\% (MBCS) (Figure 2).

\section{Lipid metabolism and oxidative status}

NEFA was affected by both BCS $(\mathrm{p}<0.01)$ and time $(\mathrm{p}<0.01)$, while BHBA was only affected by BCS $(\mathrm{p}<0.01)$. There were no BCS $\times$ time effects on NEFA $(p=0.21)$ or BHBA $(p=0.97)$ during the transition period (Table 3 ). The serum levels of NEFA in cows in the HestBCS group on the calving day and after calving were all higher than those observed in other groups $(\mathrm{p}<0.05)$. In addition, the concentrations of BHBA 
Table 1. Ingredients ( $\mathrm{kg} / \mathrm{head} / \mathrm{d})$ and chemical composition (\% of dry matter) of the experimental diets

\begin{tabular}{|c|c|c|c|c|}
\hline Items & $\begin{array}{c}\text { Far-off diet } \\
(-60 \mathrm{~d} \text { to }-22 \mathrm{~d})\end{array}$ & $\begin{array}{l}\text { Close-up diet } \\
\text { (-21 d to calving) }\end{array}$ & $\begin{array}{l}\text { Lactation diet I } \\
\text { (calving to } 21 \mathrm{~d} \text { ) }\end{array}$ & $\begin{array}{l}\text { Lactation diet II } \\
(22 \mathrm{~d} \text { to } 100 \mathrm{~d})\end{array}$ \\
\hline \multicolumn{5}{|l|}{ Ingredients } \\
\hline Corn silage & 6.00 & 12.00 & 14.00 & - \\
\hline Fermented rice straw & 7.00 & - & - & - \\
\hline Alfalfa hay & - & - & 3.70 & 4.00 \\
\hline Wet distilled grain solubles & - & 3.00 & 2.00 & 5.00 \\
\hline Corn & - & 1.40 & 1.40 & 2.20 \\
\hline Urea & 0.04 & 0.05 & 0.04 & 0.07 \\
\hline Soybean & 0.70 & 0.50 & 1.50 & 2.30 \\
\hline Spouting corn bran & 0.50 & - & - & - \\
\hline Soybean hull & 0.50 & 0.70 & 0.80 & - \\
\hline Premix $\|^{2)}$ & - & 0.80 & - & - \\
\hline Premix $\amalg^{3)}$ & - & - & 0.68 & 0.68 \\
\hline Fat powder & - & & 0.15 & 0.30 \\
\hline Rumen bypass protein & - & 0.50 & 1.20 & 1.20 \\
\hline Diamond V XPC & - & 0.025 & 0.025 & 0.025 \\
\hline STA-CHOL & - & 0.056 & 0.060 & - \\
\hline Rumen-protected nicotine & - & 0.02 & 0.02 & - \\
\hline $\mathrm{KHCO}_{3}$ & - & - & 0.05 & - \\
\hline Molasses & - & - & 0.80 & 1.00 \\
\hline Wet matter (kg/head/d) & 22.24 & 23.85 & 29.42 & 45.18 \\
\hline Dry matter intake (kg/head/d) & 13.40 & 13.10 & 17.30 & 24.40 \\
\hline Calcium & 0.51 & 1.20 & 1.09 & 0.85 \\
\hline Phosphorus & 0.39 & 0.44 & 0.45 & 0.45 \\
\hline
\end{tabular}

1) Nutrients provided/kg of additive: vitamin A, 700 kIU; vitamin D 3 , 200 kIU; vitamin E, 8,500 lU; Cu, 650 mg; Zn, 1,656 mg; Mn, 1,335.6 mg; Co, 40 mg; l, 80 mg; Se, 32 mg; $\mathrm{CaCO}_{3}, 122 \mathrm{~g} ; \mathrm{CaHPO}_{4} \cdot 2 \mathrm{H}_{2} \mathrm{O}, 34 \mathrm{~g} ; \mathrm{NaCl}, 120 \mathrm{~g}$.

2) Nutrients provided/kg of additive: vitamin A, 400 kIU; vitamin $D_{3}, 100$ kIU; vitamin E, 5,000 IU; Cu, 375 mg; Zn, 345 mg; Organic Zn, 225 mg; Mn, 508.8 mg; Co, 6 mg; I, 24 mg; Organic Se, 24 mg; Ca, $143.8 \mathrm{~g} ;$ P, $13.6 \mathrm{~g} ; \mathrm{Cl}, 158.8 \mathrm{~g} ; \mathrm{S}, 49.6 \mathrm{~g}$.

3) Nutrients provided/kg of additive: vitamin A, 400 kIU; vitamin D3, 150 kIU; vitamin E, 3,000 IU; Cu, 650 mg; Zn, 2,415 mg; Mn, 1,303.8 mg; Co, 24 mg; I, 60 mg; Se, 24 mg; Ca, $157.7 \mathrm{~g} ; \mathrm{P}, 32.3 \mathrm{~g} ; \mathrm{NaCl}, 130 \mathrm{~g}$.

4) NEl (Mcal/kg DM) was calculated according to NRC [16].

were the highest $(\mathrm{p}<0.05)$ in HestBCS on precalving, calving, and postcalving days. Table 4 shows that MDA, SOD, and VA were affected by both BCS and time $(\mathrm{p}<0.05)$. There were BCS $\times$ time effects on SOD and VA during the transition pe$\operatorname{riod}(\mathrm{p}=0.05)$. The concentrations of MDA, SOD, CAT, VA, and VE (except during precalving) in HestBCS (4.5 to 5.0) cows were all higher $(\mathrm{p}<0.05)$ than those in the other groups. Positive Pearson correlation coefficients were observed for NEFA $(r=0.260)$, BHBA $(r=0.496)$, MDA $(r=0.700)$, SOD $(r=0.606)$, CAT $(r=0.342)$, VA $(r=0.245)$, and VE $(r=0.448)$ to BCS (Table 5).

\section{DISCUSSION}

In early lactation, dairy cows experience a period of NEB due to the sudden increase in requirements of the mammary glands for milk production [17]. The mobilization of adipose tissue is associated with decreasing body weight (BW), and cows in transition with higher BCS lose more BW $[18,19]$. Similar results were observed in our study as the cows in the 


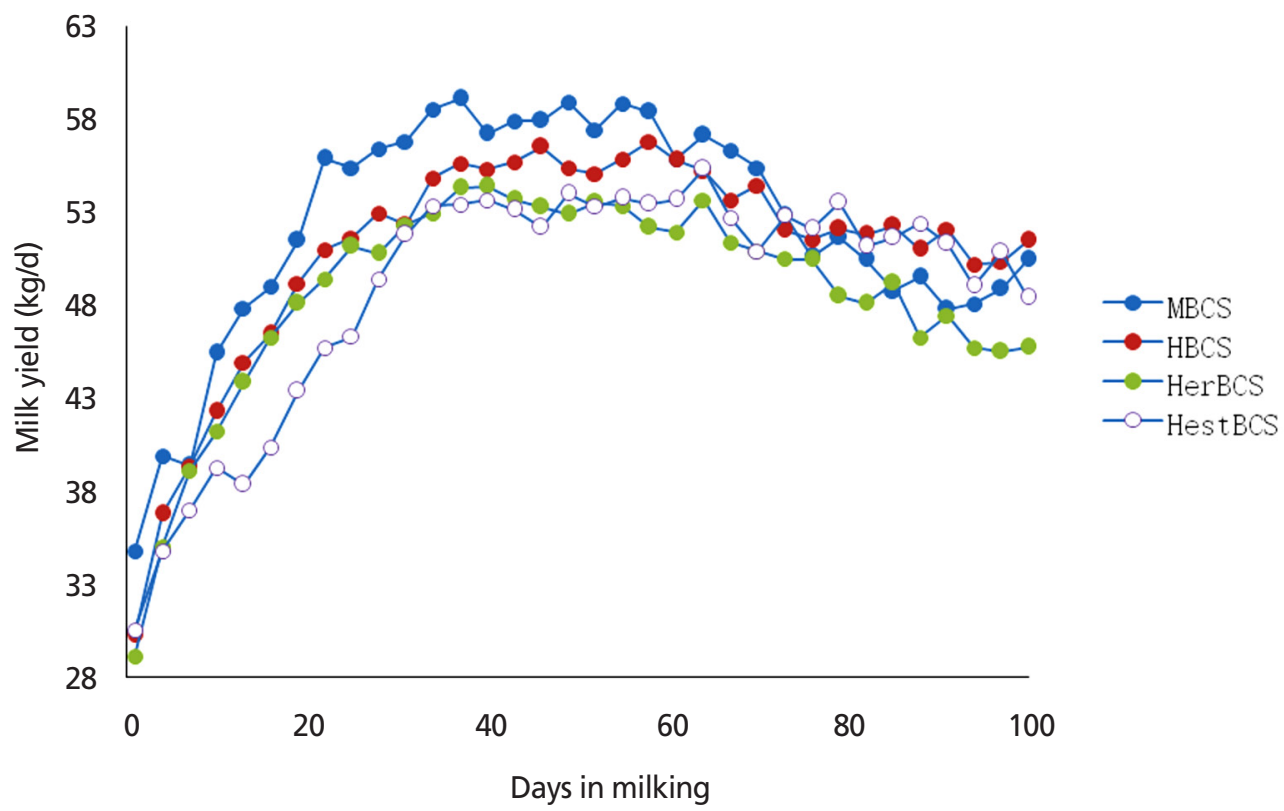

Figure 1. Average milking yield of Holstein cows after calving (0 to 100 days).

Table 2. Influence of body condition score on the colostrum composition (\%) and average milking yield ( $\mathrm{kg} / \mathrm{d}, 0$ to $100 \mathrm{~d}$ ) of Holstein cows

\begin{tabular}{lcccc}
\hline Variables & MBCS (3.0 to 3.25) & HBCS (3.5 to 3.75) & HerBCS (4.0 to 4.25) & HestBCS (4.5 to 5.0) \\
\hline Density (\%) & $19.49 \pm 4.07^{\mathrm{a}}$ & $20.30 \pm 3.19^{\mathrm{a}}$ & $20.11 \pm 4.15^{\mathrm{a}}$ & $29.39 \pm 2.77^{\mathrm{b}}$ \\
Immune globulin (\%) & $18.77 \pm 3.08^{\mathrm{a}}$ & $18.31 \pm 3.22^{\mathrm{a}}$ & $19.59 \pm 3.63^{\mathrm{a}}$ & $27.34 \pm 3.92^{\mathrm{b}}$ \\
Lactoprotein (\% & $6.06 \pm 1.08^{\mathrm{a}}$ & $5.75 \pm 1.38^{\mathrm{a}}$ & $6.57 \pm 0.99^{\mathrm{ab}}$ & $7.59 \pm 0.62^{\mathrm{b}}$ \\
Lactose (\%) & $8.84 \pm 1.14$ & $8.26 \pm 1.88$ & $9.21 \pm 1.38$ & $9.22 \pm 1.61$ \\
Solid-not-fat (\%) & $16.52 \pm 2.18$ & $17.12 \pm 2.05$ & $18.64 \pm 1.52$ & $20.06 \pm 1.45$ \\
Ash (\%) & $1.19 \pm 0.20$ & $1.12 \pm 0.29$ & $1.27 \pm 0.18$ & $1.33 \pm 0.27$ \\
Average milking yield (kg/d) & $52.35 \pm 7.03$ & $50.94 \pm 7.42$ & $48.59 \pm 3.83$ & $48.78 \pm 5.43$ \\
\hline
\end{tabular}

MBCS, medium BCS (3.0 to 3.25); HBCS, high BCS (3.5 to 3.75); HerBCS, higher BCS (4.0 to 4.25); HestBCS, highest BCS (4.5 to 5.0).

a,b Means in the same row followed by different superscripts differ at $p<0.05$.

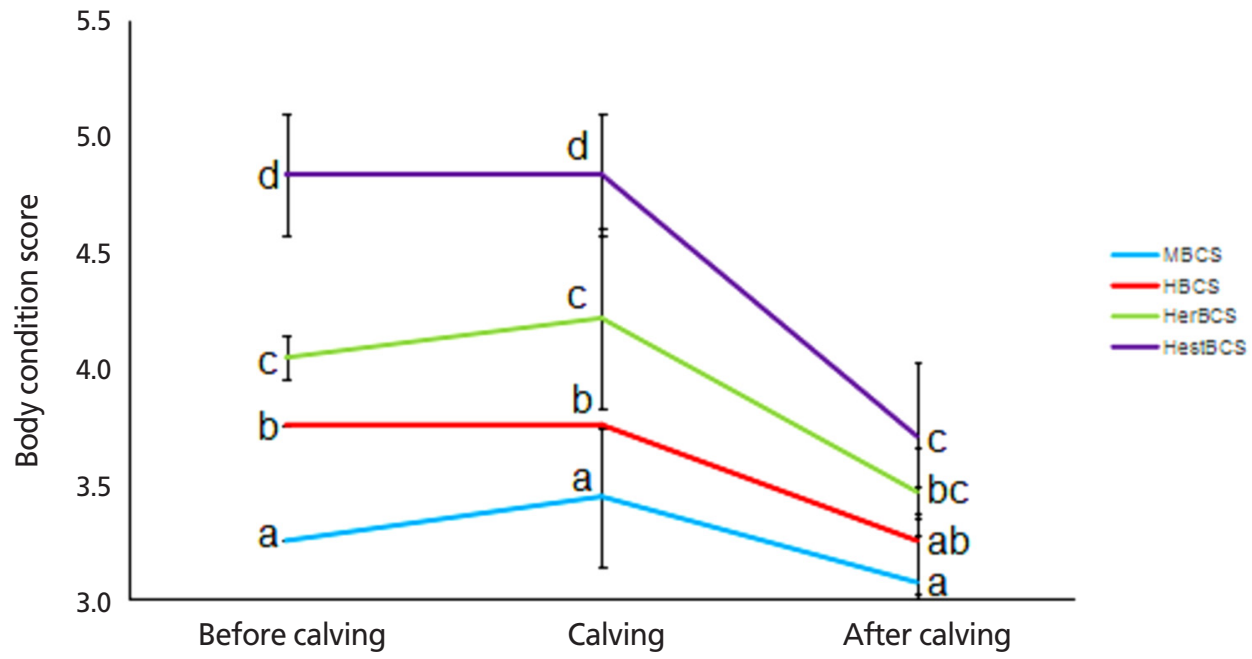

Figure 2. Body condition score of Holstein cows before calving, at calving, and after calving. ${ }^{\text {add }}$ Means in the same row followed by different superscripts differ at $p<0.05$. The same letter or no letter indicates no significant difference. 
Table 3. Influence of body condition score on the levels of non-esterified fatty acid (NEFA) and beta-hydroxybutyrate (BHBA) of Holstein cows

\begin{tabular}{|c|c|c|c|c|c|c|c|c|}
\hline \multirow{2}{*}{ Variables } & & \multicolumn{4}{|c|}{ Treatments $^{1)}$} & \multicolumn{3}{|c|}{ p-vale } \\
\hline & & MBCS (3.0 to 3.25$)$ & HBCS (3.5 to 3.75$)$ & HerBCS (4.0 to 4.25$)$ & HestBCS (4.5 to 5.0$)$ & BCS & Time & BCS $\times$ time \\
\hline \multirow{3}{*}{$\begin{array}{l}\text { NEFA } \\
\qquad(\mu \mathrm{mol} / \mathrm{L})\end{array}$} & Precalving & $1,372.50 \pm 309.31^{B}$ & $1,412.50 \pm 311.67^{B}$ & $1,535.00 \pm 351.96^{\mathrm{B}}$ & $1,730.00 \pm 446.29$ & $<0.01$ & $<0.01$ & 0.21 \\
\hline & Calving & $871.14 \pm 101.89^{a A}$ & $774.00 \pm 159.33^{\mathrm{aA}}$ & $833.00 \pm 126.91^{\mathrm{aA}}$ & $1,369.0 \pm 137.25^{b}$ & & & \\
\hline & Postcalving & $1,510.20 \pm 270.87^{\mathrm{bB}}$ & $900.50 \pm 147.92^{\mathrm{aA}}$ & $889.75 \pm 124.59^{\mathrm{aA}}$ & $1,632.50 \pm 153.60^{b}$ & & & \\
\hline \multirow{3}{*}{$\begin{array}{l}\text { BHBA } \\
\quad(\mu \mathrm{mol} / \mathrm{L})\end{array}$} & Precalving & $322.13 \pm 49.80^{a}$ & $347.96 \pm 64.95^{\mathrm{a}}$ & $409.32 \pm 58.72^{\mathrm{a}}$ & $571.37 \pm 68.07^{b}$ & $<0.01$ & 0.61 & 0.97 \\
\hline & Calving & $345.75 \pm 34.87^{\mathrm{a}}$ & $324.50 \pm 52.98^{\mathrm{a}}$ & $345.83 \pm 60.62^{\mathrm{a}}$ & $549.92 \pm 89.82^{b}$ & & & \\
\hline & Postcalving & $369.01 \pm 50.22^{a}$ & $343.23 \pm 47.27^{a}$ & $388.38 \pm 83.62^{a}$ & $559.71 \pm 66.13^{b}$ & & & \\
\hline
\end{tabular}

$B C S$, body condition score.

1) MBCS, medium BCS (3.0 to 3.25); HBCS, high BCS (3.5 to 3.75); HerBCS, higher BCS (4.0 to 4.25); HestBCS, highest BCS (4.5 to 5.0).

a,b Means in the same row followed by different superscripts differ at $p<0.05$.

$A, B$ Means in the same column followed by different superscripts differ at $p<0.05$.

Table 4. Influence of body condition score on oxidative status of Holstein cows

\begin{tabular}{|c|c|c|c|c|c|c|c|c|}
\hline \multirow{2}{*}{ Variables } & & \multicolumn{4}{|c|}{ Treatments ${ }^{1)}$} & \multicolumn{3}{|c|}{$p$-value } \\
\hline & & MBCS (3.0 to 3.25$)$ & HBCS (3.5 to 3.75$)$ & HerBCS (4.0 to 4.25$)$ & HestBCS (4.5 to 5.0$)$ & BCS & Time & BCS $\times$ time \\
\hline \multirow{2}{*}{$\begin{array}{l}\text { MDA } \\
\qquad(\mathrm{nmol} / \mathrm{mL})\end{array}$} & Precalving & $8.75 \pm 2.37^{\mathrm{a}}$ & $8.84 \pm 1.49^{\mathrm{aAB}}$ & $9.05 \pm 1.28^{\mathrm{aAB}}$ & $12.64 \pm 1.81^{\mathrm{bB}}$ & $<0.01$ & $<0.05$ & 0.16 \\
\hline & Postcalving & $8.59 \pm 1.97^{\mathrm{ab}}$ & $6.93 \pm 1.96^{\mathrm{aA}}$ & $6.69 \pm 1.52^{\mathrm{aA}}$ & $10.03 \pm 1.23^{\mathrm{bA}}$ & $<0.01$ & & \\
\hline \multirow{2}{*}{$\begin{array}{l}\text { SOD } \\
\qquad(\mathrm{U} / \mathrm{mL})\end{array}$} & Precalving & $177.40 \pm 27.52^{\mathrm{a}}$ & $171.08 \pm 22.67^{\mathrm{aB}}$ & $180.14 \pm 18.03^{\mathrm{aB}}$ & $256.79 \pm 25.84^{\mathrm{bA}}$ & $<0.01$ & $<0.05$ & 0.05 \\
\hline & Calving & $191.46 \pm 32.91^{\mathrm{a}}$ & $177.01 \pm 23.70^{a B}$ & $192.71 \pm 25.65^{\mathrm{aB}}$ & $348.58 \pm 23.43^{\mathrm{bB}}$ & $<0.01$ & & \\
\hline \multirow{3}{*}{$\begin{array}{l}\text { CAT } \\
\qquad(\mathrm{U} / \mathrm{mL})\end{array}$} & Precalving & $139.96 \pm 27.46^{a}$ & $137.81 \pm 28.03^{\mathrm{a}}$ & $132.66 \pm 18.75^{a}$ & $196.25 \pm 32.81^{b}$ & $<0.01$ & 0.51 & 0.47 \\
\hline & Calving & $126.49 \pm 18.16^{a}$ & $120.44 \pm 18.30^{a}$ & $119.56 \pm 13.79^{a}$ & $198.61 \pm 20.01^{b}$ & $<0.01$ & & \\
\hline & Postcalving & $148.05 \pm 27.20^{\mathrm{a}}$ & $122.45 \pm 45.15^{a}$ & $144.79 \pm 59.91^{\mathrm{a}}$ & $207.02 \pm 45.58^{b}$ & $<0.01$ & & \\
\hline \multirow{3}{*}{$\begin{array}{l}\text { VA } \\
\qquad(\mathrm{ng} / \mathrm{mL})\end{array}$} & Precalving & $79.45 \pm 15.02^{\mathrm{aB}}$ & $61.36 \pm 20.36^{\mathrm{aA}}$ & $62.24 \pm 21.59^{\mathrm{aA}}$ & $113.15 \pm 25.84^{\mathrm{bA}}$ & $<0.01$ & $<0.05$ & 0.05 \\
\hline & Calving & $65.60 \pm 11.42^{\mathrm{aB}}$ & $64.89 \pm 13.09^{\mathrm{aA}}$ & $71.44 \pm 13.44^{\mathrm{aA}}$ & $123.20 \pm 19.61^{\mathrm{bAB}}$ & & & \\
\hline & Postcalving & $62.22 \pm 12.64^{\mathrm{aA}}$ & $108.88 \pm 11.37^{\mathrm{bB}}$ & $123.63 \pm 24.73^{\mathrm{bB}}$ & $135.30 \pm 9.55^{\mathrm{CAB}}$ & & & \\
\hline
\end{tabular}

BCS, body condition score; MDA, malondialdehyde; SOD, oxidase dismutase; $C A T$, catalase; VA, vitamin $A ; V E$, vitamin $E$.

1) $\mathrm{MBCS}$, medium BCS (3.0 to 3.25); HBCS, high BCS (3.5 to 3.75); HerBCS, higher BCS (4.0 to 4.25); HestBCS, highest BCS (4.5 to 5.0).

$a, b$ Means in the same row followed by different superscripts differ at $p<0.05$.

$A, B$ Means in the same column followed by different superscripts differ at $p<0.05$.

Table 5. Pearson correlation coefficients of the levels of non-esterified fatty acid and beta-hydroxybutyrate, and indices of oxidative status and body condition score of Holstein cows

\begin{tabular}{|c|c|c|c|c|c|c|c|c|}
\hline & NEFA & BHBA & MDA & SOD & CAT & VA & VE & BCS \\
\hline NEFA & - & & & & & & & \\
\hline BHBA & $0.572^{* *}$ & - & & & & & & \\
\hline MDA & 0.468 ** & $0.764^{* *}$ & - & & & & & \\
\hline SOD & $0.379^{* *}$ & $0.624^{* *}$ & $0.781^{* *}$ & - & & & & \\
\hline CAT & $0.524^{* *}$ & 0.750 ** & $0.585^{* *}$ & $0.594^{* *}$ & - & & & \\
\hline VA & $0.354^{* *}$ & $0.636^{* *}$ & $0.375^{* *}$ & $0.487^{* *}$ & $0.512^{* *}$ & - & & \\
\hline VE & $0.417^{* *}$ & $0.788 * *$ & 0.741 ** & $0.671 * *$ & $0.527 * *$ & $0.639 * *$ & - & \\
\hline BCS & $0.260^{*}$ & 0.496 ** & 0.700 ** & $0.606^{* *}$ & $0.342^{* *}$ & $0.245^{*}$ & $0.448^{* *}$ & - \\
\hline
\end{tabular}

NEFA, non-esterified fatty acid; BHBA, beta-hydroxybutyrate; MDA, malondialdehyde; SOD, oxidase dismutase; CAT, catalase; VA, vitamin A; VE, vitamin E; BCS: body condition score.

${ }^{*} p<0.05$, * $p<0.01$. 
HestBCS group had the greatest BCS loss at $21 \mathrm{~d}$ after calving. Loker et al [20] suggested that lower production is associated with greater BCS. In our study, animals in the HestBCS group had a delayed peak milk yield. However, Dechow et al [21] found that fatter cows with more loss of BCS in early lactation have greater milk production. Milk composition is positively associated with BCS, and higher calving BCS means more protein and lactose during early lactation [22,23]. In our research, a higher level of lactoprotein was observed in HestBCS cows.

The NEFA and BHBA are commonly measured as indices of NEB and fat oxidization, and their concentrations during the early postpartum period are associated with BCS $[10,19$, 24,25]. The NEFA concentration in blood can be a reason for adipose tissue mobilization due to excess acetyl CoA generated from $\beta$-oxidation into ketone bodies, this leads to the loss of BCS [26,27]. In the present study, more rapid BCS loss and higher levels of NEFA and BHBA after calving were found in HestBCS cows, which is consistent with the results of Adrien et al [28]. Barletta et al [19] indicated that cows that lost BCS during the transition period had higher concentrations of NEFA and BHBA and more health events during the lactation. However, Mansouryar et al [23] fund that there was no significant differences in concentrations of NEFA and BHBA in high and normal BCS cows in early lactation. A BCS of 3.5 or higher at calving is associated with increased risk for ketosis [15], and a concentration of BHBA $\geq 1,200$ $\mu \mathrm{mol} / \mathrm{L}$ is considered as a sign of clinical ketosis $[29,30]$. However, no cows in the present study were diagnosed as ketotic at 1 week postpartum, as the BHBA concentrations were all lower than 1,200 $\mu \mathrm{mol} / \mathrm{L}$. This may be because choline (STACHOL) was added in the close-up diet [31] and PG was orally fed to cows at 4 days postpartum [32,33].

The MDA is the end product of the oxidative destruction of lipids, and its content can indicate the oxidative status of dairy cows $[34,35]$. In the present study, the highest level of MDA was found in HestBCS cows and MDA were increased on the calving day and decreased after calving. These data demonstrate that cows suffered the most serious oxidative stress on calving day and cows with higher BCS suffered much more serious oxidative stress than the other BCS cows before or after calving. It is probable that a negative association between BCS and dry matter intake in early lactation [36]. To maintain the requirements for milk production, prepartum cows with higher BCS experience more serious NEB [17].

The SOD is considered to be the first defense against pro-oxidants that convert the superoxide $\left(\mathrm{O}_{2}^{-}\right)$to hydrogen peroxide $\left(\mathrm{H}_{2} \mathrm{O}_{2}\right)$ [37] and Bernabucci et al [38] used SOD in blood to assess the oxidative status of transition dairy cows. In the current study, HestBCS cows had the highest SOD concentrations. And the concentration of SOD was commonly higher on calving day which was similar to the report of Bernabucci et al [15]. CAT is a critical antioxidant enzyme that prevents the accumulation of $\mathrm{H}_{2} \mathrm{O}_{2}$ and is considered to be an index of antioxidative status $[39,40]$. In the present study, CAT and MDA showed positive correlations, which is consistent with a previous study [35].

The VA and VE are fat-soluble membrane antioxidants that are important for enhancing antioxidant defense systems against oxidative stress $[41,42]$. Jin et al [43] reported that a diet supplemented with VA increases the concentration of serum SOD and CAT, which is consistent with the results of the current study. The VE supplementation reduces oxidative damage in the livers of heifers [44] and mitigates oxidative stress in crossbred cows [45]. In the present study, an oxidative (NEFA, BHBH, MDA)-antioxidative (SOD, CAT, $\mathrm{VA}, \mathrm{VE}$ ) balance was obviously observed in the cows, which might be the result of homeostatic control.

\section{CONCLUSION}

This study indicates that the milk yield, lipid metabolism, and oxidative status of Holstein cows are related to prepartum BCS and BCS loss during the transition period. Holstein cows with MBCS have better milk yield performance after calving whereas the animals with HestBCS suffer greater BCS loss and higher oxidative stress. Our data may provide some theoretical basis for improving the postpartum health and performance of dairy cows by adjusting prepartum BCS.

\section{CONFLICT OF INTEREST}

We certify that there is no conflict of interest with any financial organization regarding the material discussed in the manuscript.

\section{ACKNOWLEDGMENTS}

The study was financially supported by Jilin Province Science and Technology Key Project (20160301003NY) and Jilin Province Feed Engineering and Technology Research Center (20170623075TC). The authors would like to thank Dr Yang Zhi Liu and Dr Zhe Sun for their helps during the submission.

\section{REFERENCES}

1. Esposito G, Irons PC, Webb EC, Chapwanya A. Interactions between negative energy balance, metabolic diseases, uterine health and immune response in transition dairy cows. Anim Reprod Sci 2013;144:60-71. https://doi.org/10.1016/j.anirepro sci.2013.11.007

2. Alharthi A, Zhou Z, Lopreiato V, Trevisi E, Loor JJ. Body condition score prior to parturition is associated with plasma and 
adipose tissue biomarkers of lipid metabolism and inflammation in Holstein cows. J Anim Sci Biotechnol 2018;9:12. https:// doi.org/10.1186/s40104-017-0221-1

3. De Bie J, Langbeen A, Verlaet AAJ, et al. The effect of a negative energy balance status on $\beta$-carotene availability in serum and follicular fluid of nonlactating dairy cows. J Dairy Sci 2016;99: 5808-19. https://doi.org/10.3168/jds.2016-10870

4. Carlson DB, Litherland NB, Dann HM, Woodworth JC, Drackley JK. Metabolic effects of abomasal l-carnitine infusion and feed restriction in lactating Holstein cows. J Dairy Sci 2006;89:4819-34. https://doi.org/10.3168/jds.S0022-0302(06) 72531-0

5. Gross J, van Dorland HA, Bruckmaier RM, Schwarz FJ. Performance and metabolic profile of dairy cows during a lactational and deliberately induced negative energy balance with subsequent realimentation. J Dairy Sci 2011;94:1820-30. https:// doi.org/10.3168/jds.2010-3707

6. Enjalbert F, Nicot MC, Bayourthe C, Moncoulon R. Ketone bodies in milk and blood of dairy cows: Relationship between concentrations and utilization for detection of subclinical ketosis. J Dairy Sci 2001;84:583-9. https://doi.org/10.3168/jds. S0022-0302(01)74511-0

7. Roche JR, Berry DP. Periparturient climatic, animal, and management factors influencing the incidence of milk fever in grazing systems. J Dairy Sci 2006;89:2775-83. https://doi. org/10.3168/jds.S0022-0302(06)72354-2

8. Ospina PA, Nydam DV, Stokol T, Overton TR. Associations of elevated nonesterified fatty acids and $\beta$-hydroxybutyrate concentrations with early lactation reproductive performance and milk production in transition dairy cattle in the northeastern United States. J Dairy Sci 2010;93:1596-603. https:// doi.org/10.3168/jds.2009-2852

9. Edmonson AJ, Lean IJ, Weaver LD, Farver T, Webster G. A body condition scoring chart for Holstein dairy cows. J Dairy Sci 1989;72:68-78. https://doi.org/10.3168/jds.S0022-0302(89) 79081-0

10. Giuliodori MJ, Delavaud C, Chilliard Y, Becú-Villalobos D, Lacau-Mengido I, de la Sota RL. High NEFA concentrations around parturition are associated with delayed ovulations in grazing dairy cows. Livest Sci 2011;141:123-8. https://doi. org/10.1016/j.livsci.2011.05.007

11. Chebel RC, Mendonça LG, Baruselli PS. Association between body condition score change during the dry period and postpartum health and performance. J Dairy Sci 2018;101:4595614. https://doi.org/10.3168/jds.2017-13732

12. Pires JAA, Delavaud C, Faulconnier Y, Pomies D, Chilliard Y. Effects of body condition score at calving on indicators of fat and protein mobilization of periparturient Holstein-Friesian cows. J Dairy Sci 2013;96:6423-39. https://doi.org/10.3168/ jds.2013-6801

13. Akbar H, Grala TM, Riboni MV, et al. Body condition score at calving affects systemic and hepatic transcriptome indica- tors of inflammation and nutrient metabolism in grazing dairy cows. J Dairy Sci 2015;98:1019-32. https://doi.org/10.3168/ jds.2014-8584

14. Laubenthal L, Ruda L, Sultana N, et al. Effect of increasing body condition on oxidative stress and mitochondrial biogenesis in subcutaneous adipose tissue depot of nonlactating dairy cows. J Dairy Sci 2017;100:4976-86. https://doi.org/10. 3168/jds.2016-12356

15. Bernabucci U, Ronchi B, Lacetera N, Nardone A. Influence of body condition score on relationships between metabolic status and oxidative stress in periparturient dairy cows. J Dairy Sci 2005;88:2017-26. https://doi.org/10.3168/jds.S0022-0302 (05)72878-2

16. National Research Council. Nutrient requirements of dairy cattle. 7th ed. Washington, DC, USA: National Academy Press; 2001.

17. Vailati-Riboni M, Kanwal M, Bulgari O, et al. Body condition score and plane of nutrition prepartum affect adipose tissue transcriptome regulators of metabolism and inflammation in grazing dairy cows during the transition period. J Dairy Sci 2016;99:758-70. https://doi.org/10.3168/jds.2015-10046

18. Treacher RJ, Reid IM, Roberts CJ. Effect of body condition at calving on the health and performance of dairy cows. Anim Sci 1986;43:1-6. https://doi.org/10.1017/S0003356100018286

19. Barletta RV, Maturana Filho M, Carvalho PD, et al. Association of changes among body condition score during the transition period with NEFA and BHBA concentrations, milk production, fertility, and health of Holstein cows. Theriogenology 2017;104:30-6. https://doi.org/10.1016/j.therio genology.2017.07.030

20. Loker S, Miglior F, Koeck A, et al. Relationship between body condition score and health traits in first-lactation Canadian Holsteins. J Dairy Sci 2012;95:6770-80. https://doi.org/10. 3168/jds.2012-5612

21. Dechow CD, Rogers GW, Clay JS. Heritability and correlations among body condition score loss, body condition score, production and reproductive performance. J Dairy Sci 2002;85: 3062-70. https://doi.org/10.3168/jds.S0022-0302(02)74393-2

22. Roche JR, Macdonald KA, Schütz KE, et al. Calving body condition score affects indicators of health in grazing dairy cows. J Dairy Sci 2013;96:5811-25. https://doi.org/10.3168/ jds.2013-6600

23. Mansouryar M, Mirzaei-Alamouti H, Banadaky MD, Nielsen MO. Calving body condition score combined with milk test data and rectal tempreture improved the prognostic value of non-invasive markers for infectious diseases in Holestein cows. Livest Sci 2018;212:69-74. https://doi.org/10.1016/j.livsci. 2018.03.021

24. Gillund P, Reksen O, Gröhn YT, Karlberg K. Body condition related to ketosis and reproductive performance in Norwegian dairy cows. J Dairy Sci 2001;84:1390-6. https://doi.org/10. 3168/jds.S0022-0302(01)70170-1 
25. Jackson RA, Wills JR, Kendall NR, Green MJ, Murray RD, Dobson H. Energy metabolites in pre-and postpartum dairy cattle as predictors of reproductive disorders. Vet Rec 2011; 168:562. http://dx.doi.org/10.1136/vr.d1565

26. Bell AW. Regulation of organic nutrient metabolism during transition from late pregnancy to early lactation. J Anim Sci 1995;73:2804-19. https://doi.org/10.2527/1995.7392804x

27. Herdt TH. Ruminant adaptation to negative energy balance: influences on the etiology of ketosis and fatty liver. Vet Clin North Am Food Anim Pract 2000;16:215-30. https://doi.org/ 10.1016/S0749-0720(15)30102-X

28. Adrien ML, Mattiauda DA, Artegoitia V, et al. Nutritional regulation of body condition score at the initiation of the transition period in primiparous and multiparous dairy cows under grazing conditions: milk production, resumption of postpartum ovarian cyclicity and metabolic parameters. Animal 2012;6:292-9. https://doi.org/10.1017/S175173111100142X

29. Suthar VS, Canelas-Raposo J, Deniz A, Heuwieser W. Prevalence of subclinical ketosis and relationships with postpartum diseases in European dairy cows. J Dairy Sci 2013;96:292538. https://doi.org/10.3168/jds.2012-6035

30. Shin EK, Jeong JK, Choi IS, et al. Relationships among ketosis, serum metabolites, body condition, and reproductive outcomes in dairy cows. Theriogenology 2015;84:252-60. https:// doi.org/10.1016/j.theriogenology.2015.03.014

31. Lima FS, Sa Filho MF, Greco LF, Santos JEP. Effects of feeding rumen-protected choline on incidence of diseases and reprouction of dairy cows. Vet J 2012;193:140-5. https:/doi.org/ 10.1016/j.tvjl.2011.09.019

32. Christensen JO, Grummer RR, Rasmussen FE, Bertics SJ. Effect of method of delivery of propylene glycol on plasma metabolites of feed-restricted cattle. J Dairy Sci 1997;80:5638. https://doi.org/10.3168/jds.S0022-0302(97)75971-X

33. Piantoni P, Allen MS. Evaluation of propylene glycol and glycerol infusions as treatments for ketosis in dairy cows. J Dairy Sci 2015;98:5429-39. https://doi.org/10.3168/jds.2015-9476

34. Castillo C, Hernandez J, Valverde I, et al. Plasma malonaldehyde (MDA) and total antioxidant status (TAS) during lactation in dairy cows. Res Vet Sci 2006;80:133-9. https:// doi.org/10.1016/j.rvsc.2005.06.003

35. Sharma N, Singh NK, Singh OP, Pandey V, Verma PK. Oxidative stress and antioxidant status during transition period in dairy cows. Asian-Australas J Anim Sci 2011;24:479-84. https://doi.org/10.5713/ajas.2011.10220
36. Garnsworthy P, Topps J. The effects of body condition at calving, food intake and performance in early lactation on blood composition of dairy cows given complete diets. Anim Sci 1982;35:121-5. https://doi.org/10.1017/S000335610000088X

37. Halliwell B, Chirico S. Lipid peroxidation: its mechanism, measurement, and significance. Am J Clin Nutr 1993;57: 715S-25S. https://doi.org/10.1093/ajcn/57.5.715S

38. Bernabucci U, Ronchi B, Lacetera N, Nardone A. Markers of oxidative status in plasma and erythrocytes of transition dairy cows during hot season. J Dairy Sci 2002;85:2173-9. https://doi.org/10.3168/jds.S0022-0302(02)74296-3

39. Glorieux C, Sandoval JM, Fattaccioli A, et al. Chromatin remodeling regulates catalase expression during cancer cells adaptation to chronic oxidative stress. Free Radic Biol Med 2016;99:436-50. https://doi.org/10.1016/j.freeradbiomed. 2016.08.031

40. Li Y, Wei L, Cao J, et al. Oxidative stress, DNA damage and antioxidant enzyme activities in the pacific white shrimp (Litopenaeus vannamei) when exposed to hypoxia and reoxygenation. Chemosphere 2016;144:234-40. https:/doi.org/ 10.1016/j.chemosphere.2015.08.051

41. Ibrahim W, Lee US, Yeh CC, Szabo J, Bruckner G, Chow CK. Oxidative stress and antioxidant status in mouse liver: effects of dietary lipid, vitamin E and iron. J Nutr 1997;127:1401-6. https://doi.org/10.1093/jn/127.7.1401

42. Kleczkowski M, Kluciński W, Sikora J, Zdanowicz M. Role of antioxidants in the protection against oxidative stress in cattle--trace elements and enzymatic mechanisms (Part 3). Pol J Vet Sci 2004;7:233-40.

43. Jin L, Yan S, Shi B, et al. Effects of vitamin A on the milk performance, antioxidant functions and immune functions of dairy cows. Anim Feed Sci Technol 2014;192:15-23. https:// doi.org/10.1016/j.anifeedsci.2014.03.003

44. Bouwstra RJ, Goselink RMA, Dobbelaar P, Nielen M, Newbold JR, Van Werven T. The relationship between oxidative damage and vitamin $\mathrm{E}$ concentration in blood, milk, and liver tissue from vitamin E supplemented and nonsupplemented periparturient heifers. J Dairy Sci 2008;91:977-87. https://doi. org/10.3168/jds.2007-0596

45. Khatti A, Mehrotra S, Patel PK, et al. Supplementation of vitamin $\mathrm{E}$, selenium and increased energy allowance mitigates the transition stress and improves postpartum reproductive performance in the crossbred cow. Theriogenology 2017;104: 142-8. https://doi.org/10.1016/j.theriogenology.2017.08.014 